\author{
Maciej Jędrusik \\ University of Warsaw \\ Faculty of Geography and Regional Studies \\ Department of Geography of Africa, Asia and Oceania \\ e-mail: maciusik1@uw.edu.pl
}

\title{
ISLAND STUDIES. ISLAND GEOGRAPHY. BUT WHAT IS AN ISLAND?
}

\begin{abstract}
Introduction. There are institutes which research phenomena and processes taking place on islands. Such research is conducted nowadays among others at universities in France, United States, Australia, New Zealand, Great Britain and Scandinavia. Godfrey Baldacchino from the University of Prince Edward Island is a professor of Island Studies (and the editor-in-chief of the „Island Studies Journal” $)$. One of the actively operating commissions of the International Geographical Union is the IGU Commission on Islands. Therefore, the term "island" is commonly present in the modern reality and so strongly rooted that, as a results, its meaning very rarely raises doubts. Sometimes a group of researchers makes an attempt to reflect upon the definition of the term ${ }^{2}$. Those attempts are not followed by satisfying results, which does not encourage to further research on islands, be what they may.

The following article is another attempt to ponder the nature of islandness and to point those characteristics of an island which differentiate it from other geographical objects. According to the author, the group of geographical objects treated as islands is definitely too wide, and the vast protruding lands, commonly regarded as islands, continue to be islands in the universal awareness only out of habit, or due to the lack of a better, adequate term as a result of existing terminological dichotomy between the terms island/continent.
\end{abstract}

Keywords: roads, islands, insularity, isolates

We tend to envy the biologists their understanding of the term 'island' and recognition of islands as 'significant and relevant milieux'. Islands are accepted as laboratories of natural processes. Biologists have agreed that small, isolated objects surrounded by water are islands. Yet, even they use

\footnotetext{
1 "A scholarly journal dedicated to the pluri-disciplinary study of our "world of islands"” (quotation from the information leaflet on the journal).

${ }^{2}$ It has been practised, among others, by the French geographers from CRET-CEGET in Bordeaux with F. Doumenge (1982) as the leader, but also by F. Taglioni in his habilitation thesis (habilitation à diriger des recherches 2003, vol. 2 « Recherches sur les petits espaces insulaires et sur leurs organisations règionales »), as well as Taglioni (2006). Interesting theses on railway in creating or eliminating islandness have been presented by G. Baldacchino (2008).
} 
an imprecise term 'small' to define an island. Social scientists are even less precise when it comes to the definition of the term. The lack of precise definition makes it difficult to draw conclusions. May be the fact that the islands are either non-existent or ill-defined, and it is not the islandness but the isolation that should serve as an inspiration for the philosophical divagations.

\section{BUT WHAT IS AN ISLAND?}

An island is usually defined as an object which is smaller than a continent, whereas a continent is defined as larger than an island. The line between an island and a continent has been drawn arbitrarily. However only the traditionally accepted features can distinguish islands from continents and formally it is not possible to draw the line between the two geographical objects. Therefore one may start to doubt whether the accepted definitions are sufficient. An argument in favour of drawing the line between island/ continent in the case of Greenland and Australia tends to be a significant difference in size of the two objects and the fact that there are no other lands with surface fitting into the range between 2.2 and 7.7 million square meters. Australia is almost three and a half times larger than Greenland. Yet, Greenland is in turn almost three times larger than New Guinea which is the next one on the list!

Renaud Paulian noted that, apart from the Malay Archipelago 'with its continental character obviously well-known', most of the tropical islands with a few exceptions - are smaller than 3,000 sq. kilometres and the surface of numerous islands does not exceed several dozens sq. kilometres (Paulian, 1984, p.70). This observation may easily be extended to encompass the whole globe. Among several hundreds thousands of islands worldwide only 18 have surface greater than 100,000 sq. kilometres. Has the agreed line, which defines an island and is based on island's surface, been drawn correctly?

Or perhaps Pierre Gourou was right when he expressed his doubts in the very existence of islands in the following words: 'first and foremost - what is an island, what is an island's isolation? What is the maximum surface up to which an object is treated as an island? Is Australia an island? And New Guinea, and Borneo (Kalimantan), and Madagascar? How many kilometres of the sea are needed for the land to be considered isolated? Are the Danish islands to be considered islands from the human geography point of view? Is Euboea an island? Not? How about Sicily? Search for the answers to these questions is pointless and does not bring any hope for a meaningful result. Neither the size nor the vicinity of the continent is a sufficient criterion' (1973, p.121). Therefore, attempts are being made to create a new taxonomy and new definitions, inter alia 'a real island'. For instance, François Doumenge (1983) intuitively assumed that real islands have to be smaller than 10,000 sq. kilometres and objects with surface greater than 50,000 sq. kilometres are 'island-continents'. 
But what characteristic, social-related features should a 'real island' possess? The most important condition is of course its population. The social and economic behaviours of the population may play a role of distinctive features here. According to M. Jędrusik (2005) and others, economic history of tropical islands indicates that, apart from the exploitation of the inside of the island (agriculture, at times mining, less frequently exploitation of forests), dominating activities have been those related with water (fishery, interisland commerce, currently - 3S tourism, fishing licence brokerage business, using exclusive economic zones), or with isolation (benefits from existence of a microstate, tax paradises, etc.). A 'real' island should therefore be characterised with those set of features - connected with the vicinity of water or the isolation. Yet, numerous geographical objects called islands are far from such assumptions.

\section{IS MADAGASCAR AN ISLAND?}

Let Madagascar serve as an example. Commonly recognised as an island, and being one of the largest islands in the world, Madagascar takes up a surface of around 600,000 sq. kilometres. To the west the island is surrounded by the waters of the Mozambique Channel and to the East - the Indian Ocean, the two bodies of water creating a natural barrier isolating Madagascar from the continents. In geographical terms the object is heavily isolated. The effect of, as well as the evidence to such a separateness and isolation is a large number of relict and endemic species in the local flora and, most profoundly, fauna. It may be assumed that from a natural science point of view Madagascar fulfils the criteria that define islands.

When it comes to the settlement, economy and the transportation network, the picture looks much different. The majority of more than 17 million inhabitants (2005) lives far away from the coast. More than a half of Madagascar's population has connected their lives with the inside of the island rather than with the ocean. It mostly concerns the Merina ( $24 \%$ of the population), the largest and the dominant group in the modern history of Madagascar, scattered around the northern part of the central plateau. Population density on the western coast rarely exceeds 10 persons/ sq. km and on the eastern coast only here and there reaches 60 persons $/ \mathrm{sq}$. km. As a comparison - inside the central plateau, between Antananarivo and Fianarantsoa, it exceeds 80 or even 100 persons/sq. km (Madagasikara..., 2006, p.4).

Fishery - the only significant activity related with the sea - plays a third role. The size of the catch in 2005 only slightly exceeded 150000 tones. The majority of caught fish is meant for overseas export, i.a. thanks to the modern refrigerating plants located in Antsiranana in the north. The domestic market is dominated by the products of agriculture rather than fishery. In the areas where the population is concentrated it is easier to buy sweet water fish and mules than seafood. These are available in large num- 


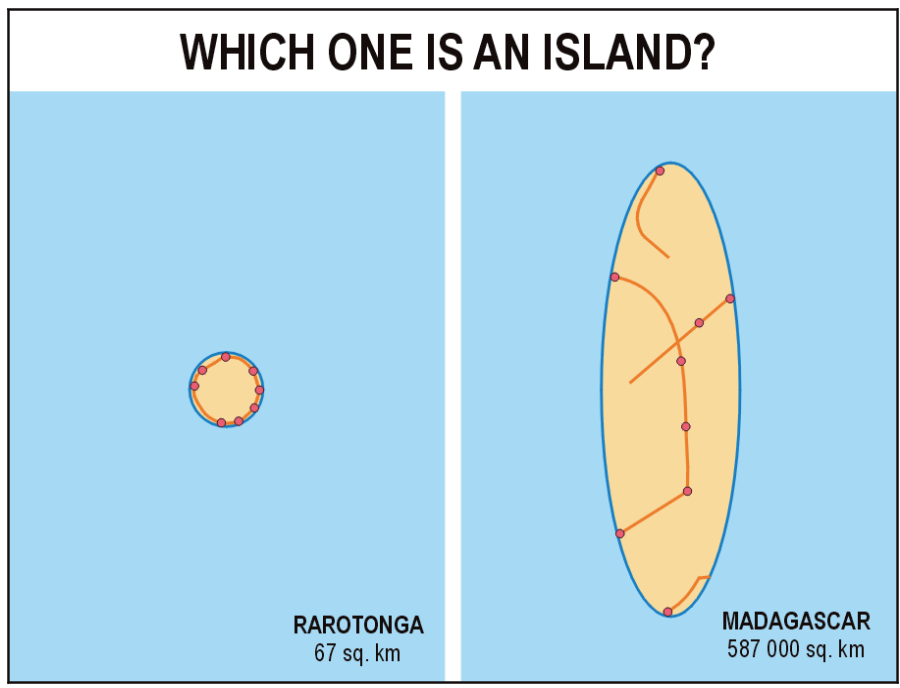

Figure 1. Ideas of spatial organisation of Rarotonga and Madagascar

bers only in the vicinity of the sea, but then it is similar as on the coasts of the continents.

The layout of transportation network is also characteristic. On the islands the most significant road is usually the one along the coast that at times bypasses hardly accessible areas. Wherever possible, the road is also built along the diameter or diagonal of the island. Such a scheme can be observed on the majority of smaller sized islands. On Madagascar, however, the layout of main roads differs significantly (Figure 1).

Taking into account the above facts, it is hard to call Madagascar an island. How is the life and everyday activities of a Malagasy person who stems from the Merina group, is not familiar with the sea and lives on the central plateau, different from day-to-day life of, for instance, an inhabitant of the Abyssinian Highlands? And the Malagasy people of such characteristics make up the majority of the country's population. How can you distinguish the life of a Malagasy person from the coastal Antakarana group from the life of inhabitants of, for instance, the coast of Tanzania? Their connections with the sea are similar. That means that on Madagascar one may observe similar diversity of living and economic activity as on many continental areas. It is difficult, however, to see how in these terms Madagascar can be regarded as closely related to islands. Similar to the features of Madagascar are those of Borneo - with its several developed coastal sections, numerous housing areas inside the island and almost utterly deserted centre. On New Guinea numerous tribes aren't familiar not only with the sea, but also with one another.

Thus, it may be assumed that the size of the territory triggers the decline of islandness (Figures 2 and 3). This issue was also discussed by oft-quoted 


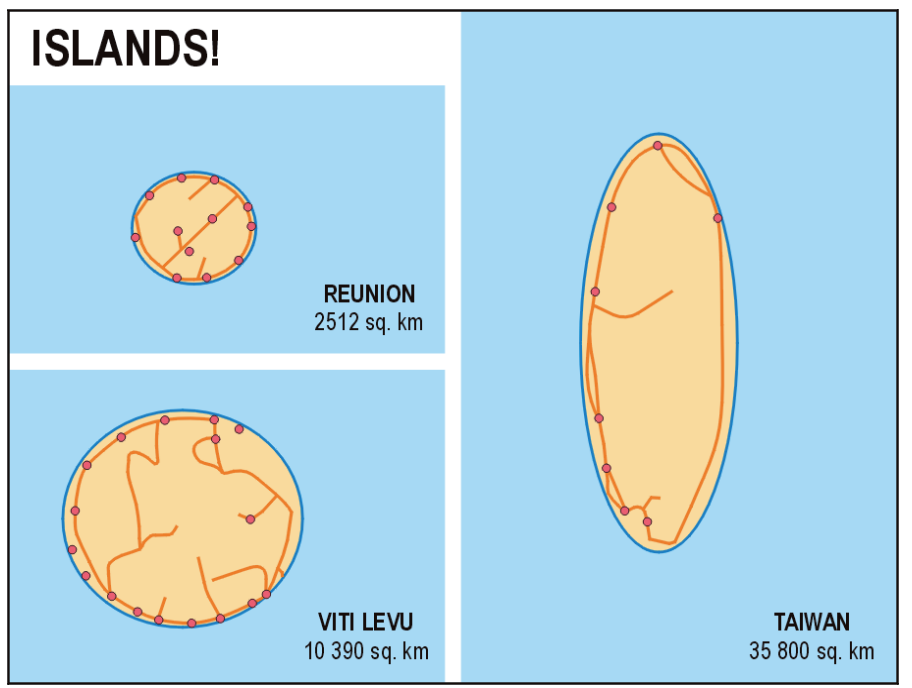

Figure 2. Ideas of spatial organisation of Reunion, Viti Levu and Taiwan

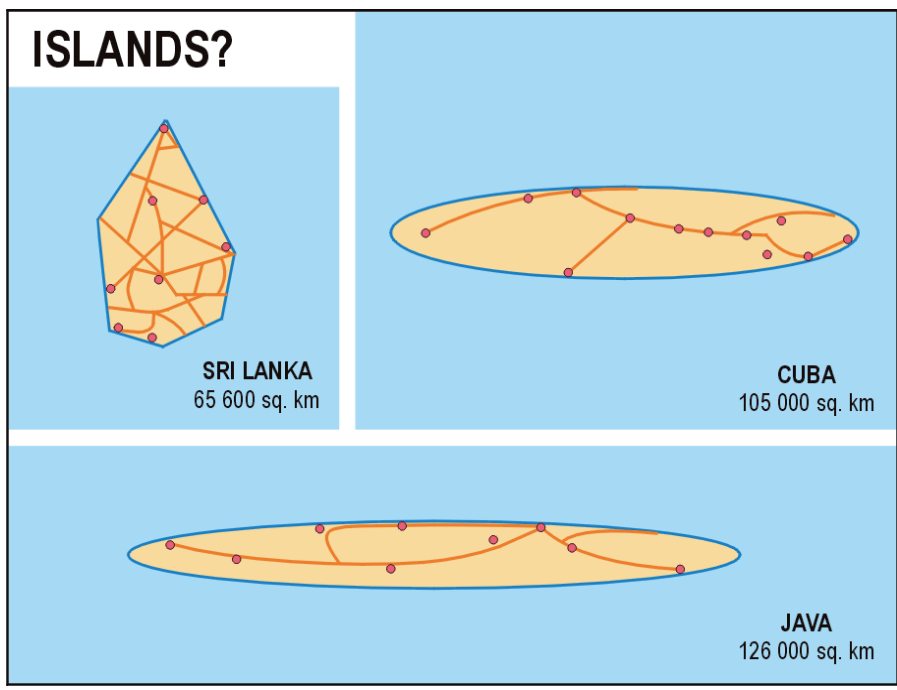

Figure 3. Ideas of spatial organisation of Sri Lanka, Cuba and Java

F. Doumenge: 'while island features may be already noticeable on the small islands just off the continental coasts, they tend to be more and more blurred when the size of the surface and the emergent land increases' (Doumenge, 1984, p. 9). He proposed the above limits of 'islandness' basing them, however, on nothing more than his intuition and experience. 


\section{WHICH ISLANDS ARE ‘REAL’?}

If islandness may so strongly depend on the size of the territory, it is worth seeing how the above mentioned social and economic criteria are shaped on the objects of different sizes which are commonly considered islands. The two features particularly taken into consideration here have been a relatively stable outline of the settlement network and the road network (Table 1). Employment structure has served as an additional criterion, rather imprecise due to the poor quality of the data and high degree of generalization. A high percentage of people employed in the service sector may, yet not necessarily, indicate stronger connection of the population with the sea. The structure of settlement and road networks have been presented on the ideograms.

Table 1. Features of selected islands

\begin{tabular}{|c|c|c|c|c|c|c|c|}
\hline \multirow[t]{2}{*}{ Island } & \multirow[t]{2}{*}{$\begin{array}{l}\text { Surface } \\
\text { (sq. km) }\end{array}$} & \multirow[t]{2}{*}{$\begin{array}{c}\text { Features of } \\
\text { settlement } \\
\text { network }\end{array}$} & \multirow[t]{2}{*}{$\begin{array}{l}\text { Features of } \\
\text { road network }\end{array}$} & \multicolumn{3}{|c|}{$\begin{array}{c}\text { Employment } \\
\text { structure acc. } \\
\text { to sectors (\%) } \\
2008 \text { est. }\end{array}$} & \multirow[t]{2}{*}{$\begin{array}{c}\text { Island } \\
\text { ness }\end{array}$} \\
\hline & & & & I & II & III & \\
\hline $\begin{array}{l}\text { Madagascar } \\
\text { (a) }\end{array}$ & 587000 & $\begin{array}{l}\text { Mainly inside the } \\
\text { island }\end{array}$ & $\begin{array}{l}\text { Main internal } \\
\text { road }\end{array}$ & 78 & 7 & 15 & - \\
\hline Java & 126000 & $\begin{array}{l}\text { Scattered } \\
\text { (inside the island } \\
\text { and on the coast) }\end{array}$ & $\begin{array}{l}\text { Main internal } \\
\text { road (branches } \\
\text { along the coast) }\end{array}$ & 42 & 19 & 39 & $+/-$ \\
\hline Cuba (b) & 105000 & $\begin{array}{l}\text { Scattered } \\
\text { (inside the island } \\
\text { and on the coast) }\end{array}$ & $\begin{array}{l}\text { Main internal } \\
\text { road (branches } \\
\text { along the coast) }\end{array}$ & 29 & 15 & 56 & $+/-$ \\
\hline Sri Lanka & 65600 & $\begin{array}{l}\text { Scattered } \\
\text { (inside the island } \\
\text { and on the coast) }\end{array}$ & $\begin{array}{l}\text { Radial from the } \\
\text { centre to the } \\
\text { coastlines }\end{array}$ & 33 & 26 & 41 & $+/-$ \\
\hline Taiwan & 35800 & Along the coasts & Along the coasts & 5 & 37 & 58 & + \\
\hline Viti Levu (c) & 10390 & Along the coasts & Along the coasts & 70 & & 30 & + \\
\hline Reunion & 2510 & Along the coasts & Along the coasts & . & & . & + \\
\hline Rarotonga (d) & 67 & Along the coasts & Along the coasts & 29 & 15 & 56 & + \\
\hline
\end{tabular}

(a) 2002 (b) - 2005 (c) - data for Fiji (2001) (d) - data for Cook Islands (1995)

Source: www.cia.gov; Encyklopedia Świat i Polska 2007

The examples presented above prove the thesis about the decline of islandness features along with an increasing size of the island. Madagascar is not an island. Also Java, Cuba and even Sri Lanka demonstrate significant mixing of the features of a 'real' island and a continent. Only Taiwan (and smaller islands) fulfils the accepted criteria. That means that in the light of hitherto accepted assumptions, the set of objects called islands is definitely too numerous and the term 'island', and thus 'islandness', is misused.

It is therefore difficult to seek theoretical effects of islandness. 


\section{CRITERIA SEARCH}

If the size of the territory, as a criterion for islandness, is incorrect, one needs to search for the merit of the issue some place else. Biologists have turned to the isolation of islands and the practical consequences of this feature. Natural scientists have been most eager to accept the existence of islands. Guy Lasserre stated that 'the specificity of islands and islands' ecosystems consists in their limited surface and their isolation. Thus, the research of the endemism of species lies in the very focus of biologists' attention. For biologist the issue is simple: Islands do exist and they build a separate world' (Lasserre, 1987, p.2). Yet, E. Kolodny wrote: 'Natural scientists were the first to define the biological meaning of the term islandness as the one that defines the influence of the environment on the species isolated on the islands. It defines first and foremost the endemism, the scarce number and the survival of relict species. Then came the demographers with their concepts of biological, economic and social minimum used for the population isolates (...)'(Kolodny, 1977, p.20).

Search for the definition of an island pursued by the representatives of other disciplines have led psychologists to the following considerations: 'How do we know this is an island? An island is in our conscience. This is more important than the sensual experiences - observations. Stepping on the island may be compared to taking the veil!' (Poirier, Clapier-Valladon, 1987, p.48). Some psychoanalysts, taking into consideration among others myths and folk legends, have compared the islands surrounded by the sea to a grandmother with huge breasts. This is the concept of the sea - the feeder. And islands are the breasts? (Poirier, Clapier-Valladon, 1987, p. 49).

Attempts at finding a criterion enabling to define the islands have from time to time brought interesting results. One of such sophisticated concepts was an idea to identify the indicator, defining a relation between the surface of the exclusive economic zone and the emergent surface of the island. The greater the value of such an indicator, the more isolated and more 'real' the island. With values lower than 100 it is impossible to talk about isolation (e.g. the Caribbean arch or the archipelagos located on the south western Pacific Ocean). With values above 1,000 the isolation is already extreme (Tonga - 1001, Niue - 1505, Wallis and Futuna - 1428, Kiribati - 4900, Bermudas and the Cook Islands - 7700, Nauru - 15000, Pitcairn - 160000). The author concluded that 'the lower the indicator, the more the inhabitants of the island have to mind their neighbours and the less they believe that controlling marine potential is a vital problem. And the other way round - the higher the indicator, the greater human and economic effort is required to maintain control over marine resources. A vital obligation of each and every highly isolated island community is to participate in the wide exchange network' (Doumenge F., 1987, p.11).

The surrounding water makes the contact between the island and the continent difficult. Water is a barrier. The further from the continent the 
island lies, the more difficult it is to reach it and thus the isolation of the distant island increases. This statement is, however, only partially supported by the evidence from the observation of the expansion of plant and animal species. In their work The Theory of Island Biogeography, biologists R. MacArthur and E. Wilson (1967, p. 20) proved that there exists a relationship between the pace of species' migration and extinction with the size of the island and its distance from the continent. Out of the two features of an island - its size and the distance from the continent - it is the former that seems more significant. An increase in the number of migrating species also depends heavily on the diversity of natural environment. The authors refer to the outcomes of 1958 research conducted by Koopman. The results indicate that four times more species were observable on small, remote Grenade than on large Margarita, located just off the continental coast. The difference in species number was even more dramatic when Grenade was compared with small coastal islands Aruba and Bonaire. This fact should be traced back to the greater diversity of Grenade's natural environment (Mac Arthur, Wilson, 1967, p. 20). And this, in turn, may lead to the conclusion that a limited accessibility of an island, related to its distance from the continent, is not the only factor determining the degree of area's isolation. In any case, according to E. Kolodny, 'this isolation is relative, because islandness and isolation are not the same phenomena, even if the most isolated (yet not necessarily the least accessible) lands in the world are often islands' (Kolodny, 1977, p. 22).

Geographers have also pointed to the role of the emergent land mass. No one has, however, denied the role of distance. François Doumenge (1987) confirmed that the isolation determines a decrease in the number of endemic species and forms. On Australian reefs there are 3,000 coral species, on the coral barrier of the New Caledonia's coast - 2,500, on Fiji - 800, on Samoa - 200, and only some 30 species on the eastern Polynesian archipelagos. Even in the marine conditions species are not able to overcome the selection mechanism resulting from the isolation (Doumenge, 1987, p.10).

Sociologists have come to envy biologists. Separation causes endemism, that is maintaining species, often relicts, which are characteristic to the particular area. Sociologists find it alluring to extend such a theory to encompass groups of human beings. Some types of settlement may survive better in certain places. That is why communities populating certain areas (e.g. Terre-de-Haut des Saintes in Guadeloupe) may be considered relicts (Bonniol, 1987, p.70).

\section{SIGNIFICANCE OF THE BARRIER - ISLANDNESS VS. ISOLATION}

In his Dictionnaire de la Géographie Pierre George defines an island as a land isolated by water from all sides. Isolated, but not surrounded, 
beset. ${ }^{3}$ In many European languages, yet not in Polish, the word island is not far from the word isolation, just to mention Latin insula, French île, Italian isola, Spanish isla, or German Insel.

Does an island - in order to be an 'island' - have to be surrounded by water? Guy Lasserre claims that many features assigned solely to islands may be found on the continents, especially in the state enclaves (eg. Bhutan) or in the oasis. As early as in $1910 \mathrm{~J}$. Brunhes wrote that, apart form the marine islands, also oasis - that is islands on the stony or sandy deserts, or groups scattered in the boreal or rain forests, or those in the high mountain valleys - form small geographical worlds, types of human islands or islets. Similarly, at the beginning of the 20th century P. Vidal de la Blache claimed: 'Isolation, lack of external pressure seems to be the greatest obstacle for (...) development. In fact the communities that, as a result of surrounding geographical conditions, have found themselves somewhat aside - on the islands, in the nooks and crannies of mountains, on the deserts, or in the middle of the forest - seem to be motionless and stagnated. This is the case on Iceland, in the Tuareg community, and in Kafiristan, where archaism is the most outstanding (Vidal de la Blache 1922, p.203). E. Kolodny provided various examples of isolated areas, for instance Mount Athos in Greece, prefecture Lasithi and Sfakia region on Crete, but also Albania and Israel or even Greece during 'the cold war' (Kolodny, 1977, p.21). But not all scientists speak in favour of extending the meaning of the term 'island'. David Lowenthal noted that an enclave on the continent may be unblocked by means of building a proper road or resettling inhabitants to an urban agglomeration and damaged environment may be re-cultivated. In the case of islands it is much more difficult, if not impossible, due to the fact that their surface is too small and the efficacy of such investments is usually much lower than on the continent (Lowenthal, 1987).

Although, as far as research of human groups is concerned, the examples of 'islandness' may be found not only on classic islands. Continental equivalents of islands are oasis. And the barrier - an equivalent of water - is the desert. Yet as more examples of 'continental' islands may serve mountain valleys and plateaus, hardly accessible due to steep slopes and escapements. It is interesting to see that in the above mentioned cases an actual, geographical radial distance may in fact be short, yet the neighbouring communities can develop independently. Here it is the steep slopes that form a barrier.

French sociologist J.L. Bonniol (1987) researched particular features of islandness, basing on the examples of small islands - Terre-de-Haut des Saintes, Désirade in Guadeloupe and La Digue in the Seychelles. He wrote, for instance, '...winds, sea currents, ships and the sea (...) may favour the exchange (...). The features that separate the islands may turn out to be much less pronounced than the mountain barriers that separate valleys which form

\footnotetext{
${ }^{3}$ after G. Lasserre (1987, p.2): 'non point entourée, cernée, mais isolée'.
} 
isolates way more distinct than those of islands' (Bonniol, 1987, pp. 68-69). The sea plays a role of an actual barrier when the local population does not have the marine technology advanced enough to face the oceanic space. An example of such a community living on the Creole islands (the Antilles) is a small group of fishermen who specialize solely in cabotage. But is it only a question of technology? P. Vidal de la Blache wrote: 'A story has been told of survivors, accidentally gathered on Tristan da Cunha where they got used to living slow and passive lives, so that after two or three generations they became unable to change their habits. An intervention of an external force proves necessary' (Vidal de la Blache, 1922, p. 203). Also the settlements situated in the midst of the forest or surrounded by swamps may be considered examples of such 'continental islands'. In both examples a natural barrier excists (forest, swamp) that separates the settlement from the outside world. Such a barrier is obviously more 'penetrable' than the sea, yet still it remains a barrier. René Dubos believed that 'for many centuries isolated primitive tribes have lived in the tropical, humid jungles at the banks of Congo and the Amazon river, who extracted everything they need from the scarce natural resources which for us seem completely useless and hostile. Similarly the Eskimos for long years have led their lives on the least fertile and most abandoned areas of the Arctic, although simple tools originating form the stone age civilizations have been their only equipment (Dubos, 1970, p. 273).

What is interesting to note is the fact that field research of local communities, initiated by B. Malinowski and A. R. Radcliffe-Browne, were first conducted by means of observation of those communities which were the most separated from the outside world and that were eventually called isolates (Firth, 1965, p.8). In Oceania it were the island communities that played the role of isolates. Jean Benoist, quoting the fundamental works dealing with isolates, next to B. Malinowski's essays also lists the results of Raymond Firth's research on Tikopia (1965), Bossevain's on Malta, and Ottino's on Rangiroa. For these scientists the isolates (and thus the communities) were the objects of research way more significant than the islands themselves. An island becomes meaningful as an isolate only once the research on the community's functioning have begun (Benoist, 1987, p. 37). According to him, islandness in the social sphere results from a combination of two elements - isolation and small size of the area.

What follows from the above statement is that an isolate may be the community of Tikopia, but the same role of an isolate may likewise be played by the Meban - an isolated community of some 20,000 people living in Sudan in the area of the White Nile backwater. As long as they live in their villages, the Meban are able to hear very high-pitched sounds till the late elderhood. This feature is not a result of very quiet surrounding environment, but extremely low blood pressure. This ability is lost when their environment changes (Dubos, 1970, pp. 258-259). And also here more significant seems 
to be the fact of community's isolation rather than islandness, which is also supported by interesting results of the genetic tests conducted on the population of the Hel peninsula in Poland. According to other authors: 'the tests of the Hel peninsula population have resulted in an interesting outline of the influence of isolation barriers on the genetic composition. The peninsula itself has for centuries been populated by the Kashubians who, as a result of characteristic geographical location, natural isolation and minimal migration movements, have maintained their ethnic autonomy. Blood tests based on $\mathrm{AB} 0$ blood group system showed that in terms of serological composition this population is more similar to the population of Finland or other Baltic states than, for instance, the inhabitants of Gdansk' (Dzierżykray-Rogalski, Promińska, 1970, p.34). Thus, the inhabitants of the peninsula possess features characteristic for an isolate.

Jean Benoist stated simply that 'the boarder of an island which delimits the space is meaningless in the sociological terms as long as it does not coexists with a different kind of boarder, much more far-reaching, the one that delimits social space', and then concluded that 'isolation mechanisms that stem from the society are much stronger than those that come from the doings of the nature' (Benoist, 1987, p. 41).

\section{CONCLUSION. WAYS IN WHICH ISLAND RESEARCH MAY FURTHER BE ORIENTED}

The feature of islands, but not exclusively islands, is their isolation. In such a case the greater attention should be paid to research on isolation (as an opposite of globalisation). Yet, do isolated areas still exist in the modern era of progressive globalisation? Such areas are reached by more and more information about the world and, what frequently follows, numerous tourists. Information breaks the isolation. Isolated areas became more open and in the time perspective they cease to be isolated at all. Will they also cease to be islands?

Or perhaps it is this process of 'opening up' of the islands that is especially worth scientific research? Its effects may prove to be just as significant as the process itself. While preventing this phenomenon is unimaginable, preparing the answer to coming changes is surely worth an effort. The applicable research should focus on:

1. determining the areas (landscapes, environments) which need to be protected from the growing anthropopression (influx of tourists);

2. choice and stimulated cultivation of customs (cultural elements) worth preserving in order to cherish the cultural heritage;

3. planning a rational management of the limited area (which is an immanent feature of 'real' islands) due to an increasing internal and especially external demand. 


\section{REFERENCES}

Baldacchino G., 2008, Trains of Thought: Railways as Island Anthitheses in: Shima: The International Journal of Research into Island Cultures, vol. 2 Number $1: 29-40$

Benoist J., 1987, L'insulairité comme dimension du fait social in: Iles tropicales: insulairité, „insularisme”, CRET, Université de Bordeaux, Bordeaux : 37-44

Bonniol J.-L., 1987, Micro-insulairité et particularisme: approche comparé à partir de cas antillais et seychellois in: Iles tropicales: insulairité, „insularisme”, CRET, Université de Bordeaux, Bordeaux : 67-86

Brunhes J., 1910, La géographie humaine, Paris

Doumenge F., 1982, Aspects de la viabilité des petits pays insulaires, Paris (draft)

Doumenge F., 1984, Unité et diversité des caractères naturels des îles tropicales in: Nature et Hommes dans les îles tropicales, CEGET-CRET, Bordeaux : 9-24

Doumenge F., 1987, Quelques contraintes du milieu insulaire in: Iles tropicales: insulairité, „insularisme”, CRET, Université de Bordeaux, Bordeaux : 9-16

Dubos R., 1965, Man Adapting, Yale University Press, New Haven

Dzierżykray-Rogalski T., Promińska E., 1970, Zdolności przystosowawcze człowieka [Human adaptability], Wiedza Powszechna, Warszawa

Encyklopedia Świat i Polska 2007, 2006, WN PWN, Warszawa

Firth R., 1965, We the Tikopia, kingship in primitive Polynesia, Beacon Press, Boston

George P., 1970, Dictionnaire de la géographie, Presses Universitaires de France, Paris

Gourou P., 1973, Pour une géographie humaine, Ed. Flammarion, Paris

Huetz de Lemps A., 1987, Rapport de synthèse: ìles, insulairité, „insulairisme” in: Iles tropicales: insulairité, ,insularisme”, CRET, Université de Bordeaux, Bordeaux : 487-499

Jędrusik M., 2005, Wyspy tropikalne. W poszukiwaniu dobrobytu [Tropical Islands. Looking for well-being], WUW, Warszawa

Kolodny E.Y., 1977, La population des îles de la Grèce. Essai de géographie insulaire en méditerranée orientale, Edisud, Aix-en-Provence

Lasserre G., 1987, Le géographe et les ìles in: Iles tropicales: insulairité, „,insularisme”, CRET, Université de Bordeaux, Bordeaux : 1-6.

Lowenthal D., 1987, A propos du développement insulaire: besoin, incertitudes, résistances in: Iles tropicales: insulairité, „insularisme”, CRET, Université de Bordeaux, Bordeaux : 193-208

Mac Arthur R.H., Wilson E.O., 1967, The Theory of Island Biogeography, Princeton University Press, Princeton (New Jersey)

Madagasikara et ses 22 Régions (2006), IGHN, Antananarivo

Paulian R., 1984, Les îles, laboratories naturels: spécificité et contraintes biologiques des milieux insulaires in: Nature et Hommes dans les îles tropicales, CEGET-CRET, Bordeaux : 69-80

Poirier J., Clapier-Valladon S., 1987, Essai sur une problématique de la mythologie et de la psychologie insulaires in: Iles tropicales: insulairité, „insularisme”, CRET, Université de Bordeaux, Bordeaux : 45-56

Taglioni F., 2006, Les petits espaces insulaires face à la variabilité de leur insularité et de leur statut politique, Les Annales de géographie, $\mathrm{n}^{\circ} 652: 664-687$

Vidal de la Blache P., 1922, Principes de géographie humaine, Librairie Armand Colin, Paris

www.cia.gov (7.04.2010) 